Original Research

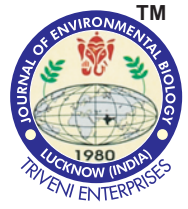

DOI : http://doi.org/10.22438/jeb/38/5/MRN-302

\title{
Competitive, stress-tolerant and ruderal based classification of some plant species in an Alpine community of the Giresun Mountains in Turkey
}

\section{Authors Info}

R. Huseyinoglu ${ }^{1 *}$ and E. Yalcin ${ }^{2}$

${ }^{1}$ Giresun University, Şebinkarahisar School of Applied Sciences, iresun, 28400, Turkey

${ }^{2}$ Department of Biology, Faculty of Arts and Science, Ondokuz Mayıs University, Samsun, 55139, Turkey

${ }^{*}$ Corresponding Author Email : rena.huseyinoglu@giresun.edu.tr

Key words

Alpine community, Competitor-ruderal, Grime's CSR strategies, Stress tolerant

Publication Info Paper received : 17.03 .2016 Revised received : 28.08 .2016 Re-revised received : 05.12 .2016 Accepted: 01.03.2017

\section{Abstract}

Aim: The CSR strategy model classifies plant species based on established strategies in dealing with two groups of external environmental factors, namely stress and disturbance. The main objective of the present study was to analyze established strategies of some characteristic plant species in the alpine belt of the Giresun Mountains in Turkey and to determine any disturbance on plant species present in the study area.

Methodology: Fifty sample plots and ninety plant species were selected from homogenous areas to determine predictor variables for Grime's CSR strategies. Canopy height (CH), dry matter content (LDMC), lateral spreading (LS), dry leaf weight (LDW), specific leaf area (SLA), flowering period (FP) and onset of flowering period (FS) were used to find Grime's strategies for the studied species.

Results: Almost all species present in the study area were allocated into nine different secondary or transient Grime's strategies. Most of these secondary or transient strategies (SC, $\mathrm{S} / \mathrm{SC}$, and SC/CSR) have a large proportion stresstolerator strategy (S). On the other hand, high number of plant species exhibited CR, C/SC, R/CR and $\mathrm{C} / \mathrm{CR}$ strategies having strong competition and ruderalism extents. $\mathrm{CR}$ (competitor-ruderal) was the most common strategy in the study area.

Interpretation: Findings suggested that plant species in the study area were exposed to more than one pressure factor. The presence of a large proportion of ruderalism demonstrates the increasing impact of disturbance (grazing and mowing) on the studied species.

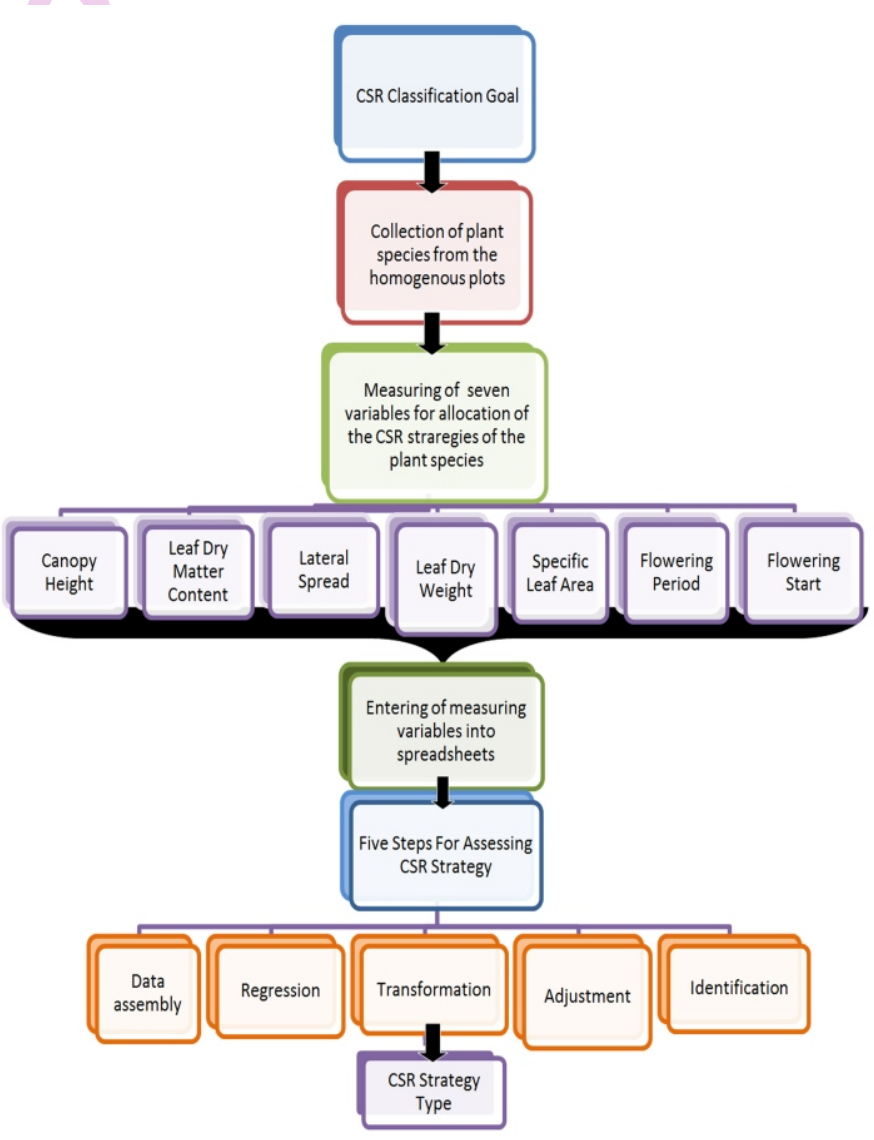




\section{Introduction}

Classification of plant species and vegetation according to life-history has a long tradition in plant ecology. This classification is essentially based on the attributes of plant species that gave them the capacity to survive under different geographic, climatic and ecological conditions and is closely linked to plant architecture and physiognomy (Vandvik and Birks, 2002). However, recent studies in plant ecology attempt to classify plant species and communities into the major functional groups that give an opportunity to predict ecosystem responses to recurring fires, grazing, inundation, biological invasions and global climate change (Magdi, 2003; Bond et al., 2005; Diaz et al., 2007; Keith et al., 2007; Zhu et al., 2012; Shryock etal., 2014).

It has been reported that some plant species behave similarly in their growth strategy in response to the environment and physiological basis of species strategies and related trait attributes is well documented in the literature, especially by Grime's C-S-R model. The term 'strategy' can be defined as a grouping of similar or analogous genetic characteristics that occurs widely among species or population and causes them to exhibit similarities in ecology (Grime, 2002). The CSR strategy model classifies plant species based on established strategies in dealing with two groups of external environmental factors, namely stress and disturbance. Stress factors include suboptimal temperatures, and shortage of water, light and mineral nutrients and these factors cause restriction of the photosynthetic production of plant species. However, the second group of external factors, namely disturbance, is comprised of factors such as soil erosion, fire, wind-damage, frosting and activities of herbivores, pathogens, man etc. Thus, disturbance factors lead to partial or total destruction of plant biomass. Grime's three-strategy model has defined three primary strategies, such as competitive (C), stresstolerant $(S)$ and ruderal $(R)$ and four secondary strategies such as competitive-ruderal (CR), competitive stress tolerant (CS), stress-tolerant ruderal (SR) and competitive stresstolerant ruderal (CSR). In addition to three primary and four secondary strategies, the CSR strategy model also defines twenty-two intermediate or transient strategies and all these strategy types can be ordinated within a triangular space (Hodgson et al., 1999).

Recent studies have shown ambiguous results in relation to apply the CSR model, especially to woody species (Pierce et al., 2013). Navas et al. (2010) used revised categories for lateral spread proposed by Grime et al., (2007) to modify CSR classification and include woody species. On the other hand, Cerabolini et al. (2010) stated that lateral spread used in CSR classification cannot be assumed as a strict predictor of competitive ability in unproductive habitats by stress tolerators. Even though the CSR model has been criticized by other authors, (Tilman, 1994; Craine, 2005) this theory is considered to be a fundamental functional classification (Hüseyinova et al., 2013) and can be successfully applied to herbaceous vegetation.
In view of the above, the present study aimed to analyze established strategies of some characteristic plant species in the alpine belt of the Giresun Mountains in Turkey and to determine whether there is disturbance impact on the plant species or not in the study area.

\section{Materials and Methods}

Study area : The present study was performed in the alpine belt of Giresun Mountains of Giresun Province, in the north-eastern part of Turkey. Giresun mountains are a system of mountains that extend up to the peaks on Karadağ mountain at $3391 \mathrm{~m}$ in the east and on the Karagöl plateauat $3095 \mathrm{~m}$ in the west.

The study area is surrounded by high mountains where subalpine Abies nordmanniana subsp. nordmanniana (Stev.) Spach forests do not develop because of climatic limitations. In the study area the alpine belt extends from 1800 m.a.s.l. (timberline) to 2600 m.a.s.l. upwards on south-facing slopes. These altitudinal boundaries run about $100 \mathrm{~m}$ lower in the northern part because of being subject to a more maritime climate.

The nearest province to the study area (Shebinkarahisar) has a Mediterranean type climate with $525 \mathrm{~mm}$ mean annual precipitation $(P)$ and a drought period that prevails in July with $0.5 \mathrm{~mm}$ precipitation. The mean annual temperature is $11.3^{\circ} \mathrm{C}$. Summer rainfall is $37 \mathrm{~mm}$. The mean maximum temperature for the hottest month and the mean minimum temperature for the coldest month $(\mathrm{m})$ is 30.3 and $16.1^{\circ} \mathrm{C}$, respectively. Index of xericity ( $\left.\mathrm{S}=\mathrm{PE} / \mathrm{ME}\right)$ is 1.8 . Pluviometric quotient $(\mathrm{Q}=2000 \mathrm{P} / \mathrm{M}+\mathrm{m}+546.4[\mathrm{M}-\mathrm{m}])$ is 40.7 and the precipitation regime is Sub Mediterranean (Spring, Autumn, Winter, Summer; Sp, Au, Wi, Su).

Alpine grasslands in the study area is characterized by Festuca pinifolia (Hackel ex Boiss.), Bornm. var. pinifolia, Sibbaldia parviflora Willd. var. parviflora, Minuartia umbellulifera (Boiss.) McNeill subsp. umbellulifera var. umbellulifera, Thymus sipyleus Boiss., Vaccinium myrtillus L., Potentilla crantzii (Crantz) Fritsch and many other species. Cover values of these species ranged from 10 to 50 . Plant species in the study area are fragile with its species and population being directly and indirectly influenced by changes in land-use practice, especially abandonment of small-scale agriculture, and fragmentation of habitats. Generally, the study site is exposed to low but frequent disturbance factors. As an important disturbance factor, grazing reduces the dominance of competitive species and by trampling creates germination niches in the bare soil. It, therefore, has a direct effect on the structure and organization of grasslands. Today, many of the pastures in the study area are still in use (i.e. mowing, grazing or both); fallow farmland of pastures can be found in different successional stages. The number of grazing cows and sheep reach 50000 individuals during the year. 


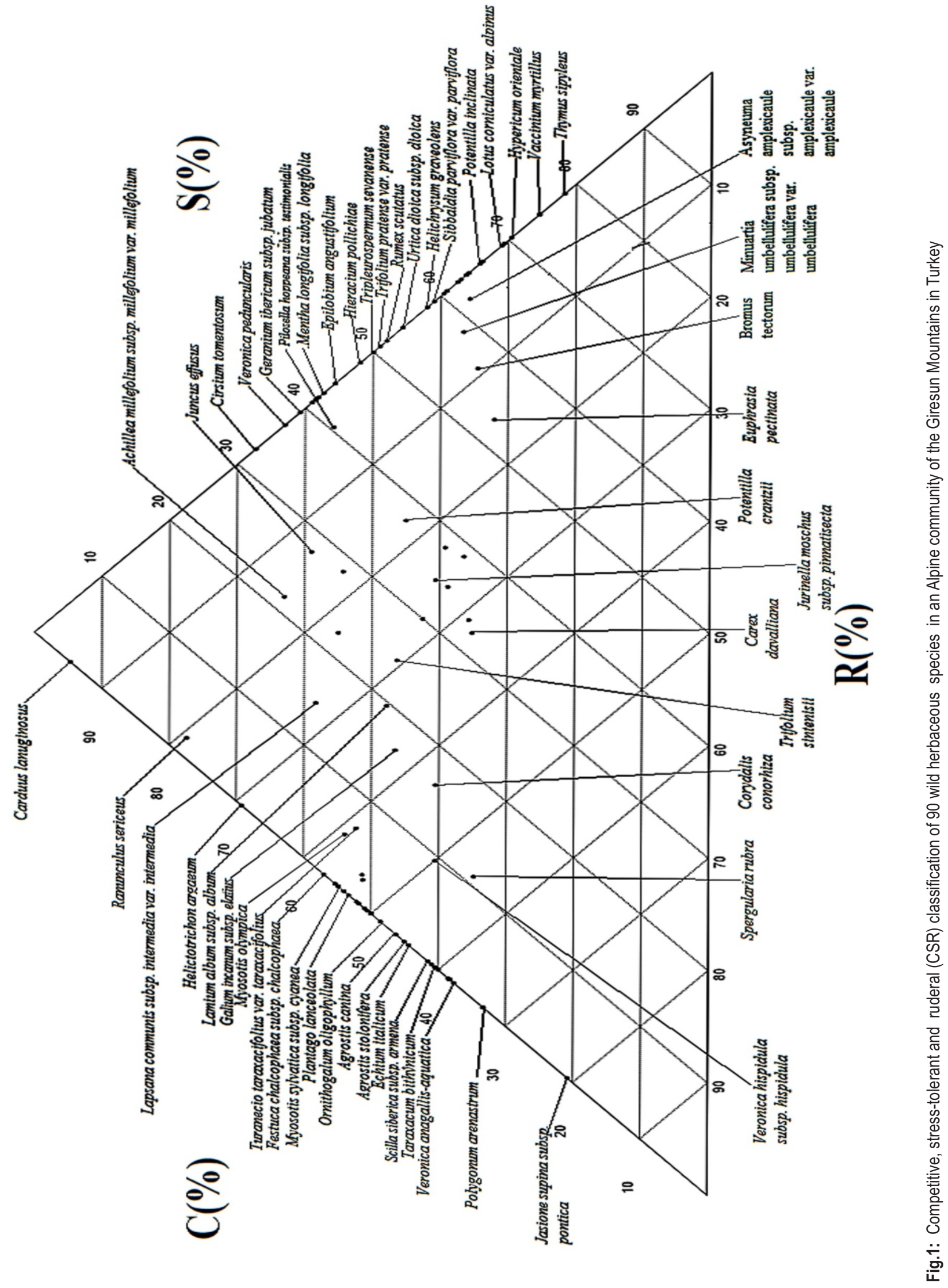


Table 1: Definition of the required parameters for allocation of the CSR strategies of plant species (Hodgson et al., 1999)

\begin{tabular}{|c|c|c|c|}
\hline \multicolumn{3}{|l|}{ Variable } & \multirow{2}{*}{$\begin{array}{l}\text { Definition } \\
1-49 \mathrm{~mm}\end{array}$} \\
\hline & & 1 & \\
\hline & & 2 & $50-99 \mathrm{~mm}$ \\
\hline & & 3 & $100-299 \mathrm{~mm}$ \\
\hline \multirow[t]{3}{*}{ Canopy height } & Six-point & 4 & $300-599 \mathrm{~mm}$ \\
\hline & classification & 5 & $600-999 \mathrm{~mm}$ \\
\hline & & 6 & $>999 \mathrm{~mm}$ \\
\hline Dry matter content & \multicolumn{3}{|c|}{ Mean of percent dry matter content in the largest, fully hydrated, fully expanded leaves (\%) } \\
\hline \multirow[t]{3}{*}{ Flowering Period } & \multicolumn{3}{|c|}{ Normal duration of flowering period (months) } \\
\hline & & 1 & First flowering in March or earlier \\
\hline & & 2 & in April \\
\hline \multirow[t]{7}{*}{ Flowering start } & Six-point & 3 & in May \\
\hline & classification & 4 & in June \\
\hline & & 5 & in July \\
\hline & & 6 & in August or later, or before leaves in spring \\
\hline & & 1 & Plant short lived \\
\hline & & 2 & $\begin{array}{l}\text { Compactly tufted about a single axis, no thickened rootstock (in non- } \\
\text { graminoids) }\end{array}$ \\
\hline & & 3 & Compactly tufted ramets appressed to each other at base (in graminoids) \\
\hline \multirow[t]{4}{*}{ Lateral spread } & Six-point & 3 & $\begin{array}{l}\text { Compactly tufted about a single axis, thickened rootstock present (in non- } \\
\text { graminoids) }\end{array}$ \\
\hline & & 4 & Shortly creeping, $<40 \mathrm{~mm}$ between ramets \\
\hline & & 5 & Creeping, $40-79 \mathrm{~mm}$ between ramets \\
\hline & & 6 & Widely creeping, $>79 \mathrm{~mm}$ between ramets \\
\hline
\end{tabular}

Vegetation sampling and ordination of species within CSR space : Fifty sample plots were selected $(4 \times 5 \mathrm{~m})$ from homogenous areas, and 90 plant species were selected from the plots with the highest cover values to determine predictor variables for Grime's CSR strategies. Species with cover values of less than $5 \%$ in these plots were excluded. Taxonomic nomenclature of Davis (1965-1985) and Davis et al. (1988) were referred and Latin names were updated following Güner et al. (2000).

Canopy height, leaf dry matter content, lateral spreading, leaf dry weight, specific leaf area, flowering period (FP) and onset of flowering period were used to find Grime's strategies for the studied species. The flowering period parameter was only required for nongraminoids (Table 1 ).

After determining seven predictor variables (six predictor variables for graminoids) for each species, these variables were entered into spreadsheets and established strategies were assessed by automatic data transformation. The CSR strategy of a specie was assessed in five steps: data assembly, regression, transformation, adjustment and identification of CSR type. Coordinate values ranged from 2.5 to 2.5; data were translated onto a positive axis with the minimum value set as zero. Prior to plotting $C, S$ and $R$ values were then converted into percentages for each species (Hodgson et al., 1999; Çakır et al., 2010).

\section{Results and Discussion}

Forty one percent of the studied species belonged to the Euro-Siberian phytogeographical region, $13.3 \%$ to the IranoTuranian phytogeographical region, and $3.3 \%$ to the Mediterranean phytogeographical region, while $42.3 \%$ of the species were pluriregional or phytogeographically uncertain.

The most abundant species (Table 2) in the study area was Festuca pinifolia var. pinifolia (cover $=50 \%$ ), that exhibited a plant strategy of CR incorporating substantial competitive and, to a slightly lesser extent, ruderal abilities $(C: S: R=52.1: 0: 47.9)$. The second most abundant species (Minuartia umbellulifera subsp. umbellulifera var. umbellulifera; cover $=20 \%$ ) exhibited a broadly stress-tolerant-competitor (SC) strategy (36.6 : 58.5 : 4.9), and the third most abundant species (Vaccinium myrtillus; cover $=15 \%$ ) demonstrated a pure stress-tolerator (S) strategy $(25.4: 74.6: 0)$. A few of the studied species (only six species) represented primary established strategies. Two of these species exhibited competitor $(C)$ strategy whereas another four species were allocated into the stress-tolerator (S) strategy. Almost all the species in the study area were allocated to nine different secondary or transient Grime's strategies (CR, SC, S/SC, C/SC, SC/CSR, C/CSR, C/SR, C/CR and R/CR) (Table 2). Some of these secondary or transient strategies (SC, S/SC, SC/CSR) also 


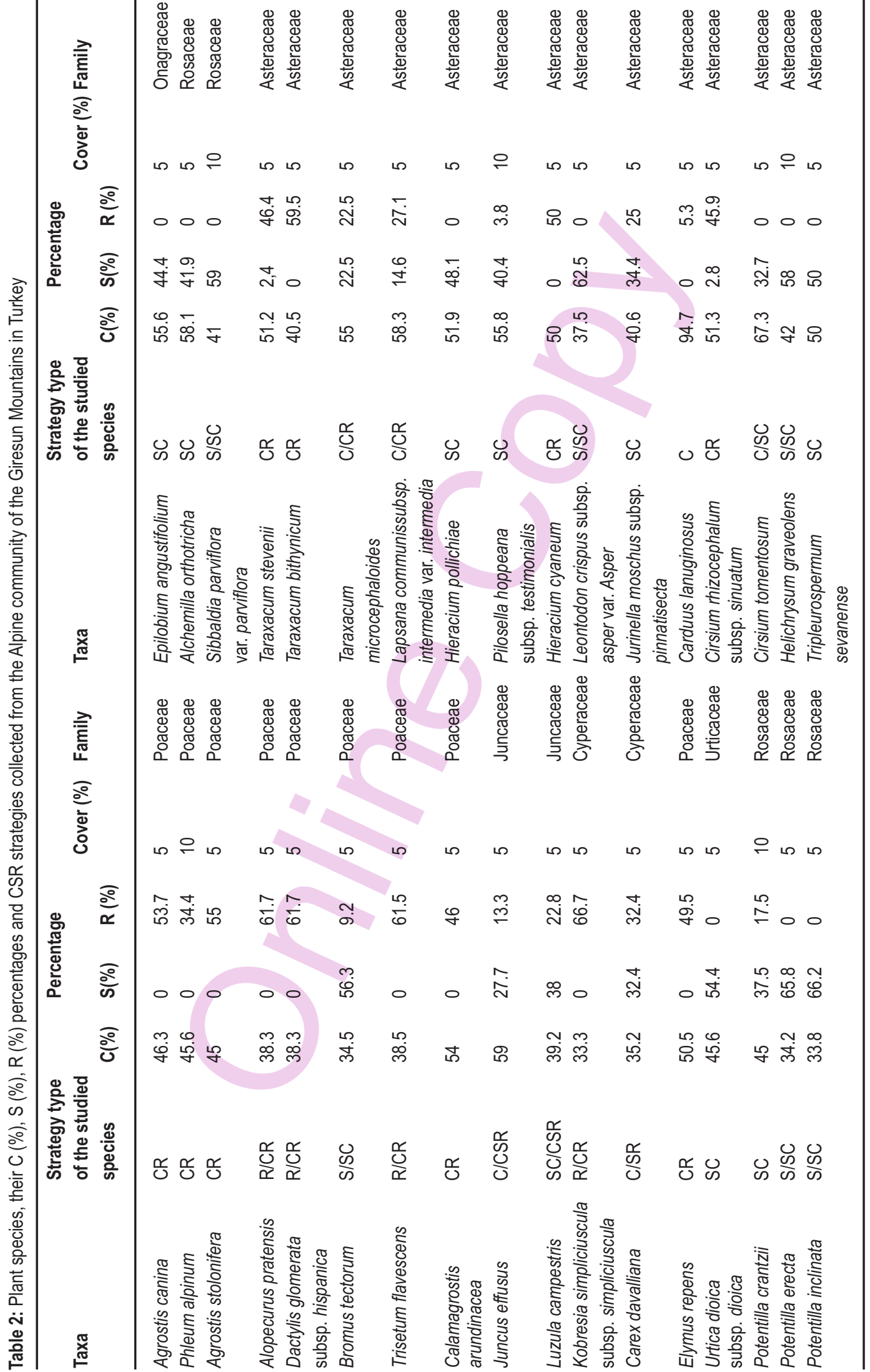




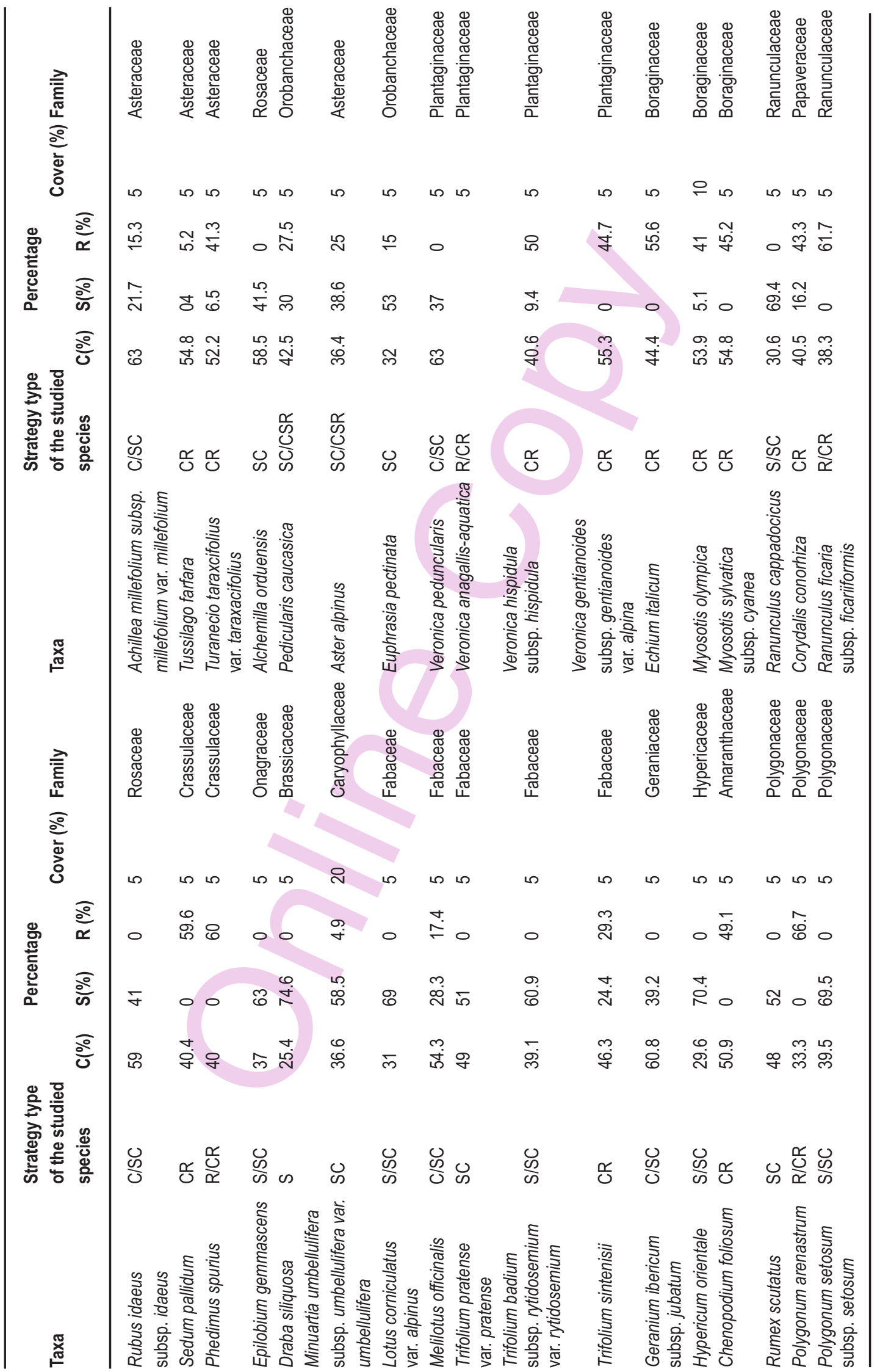




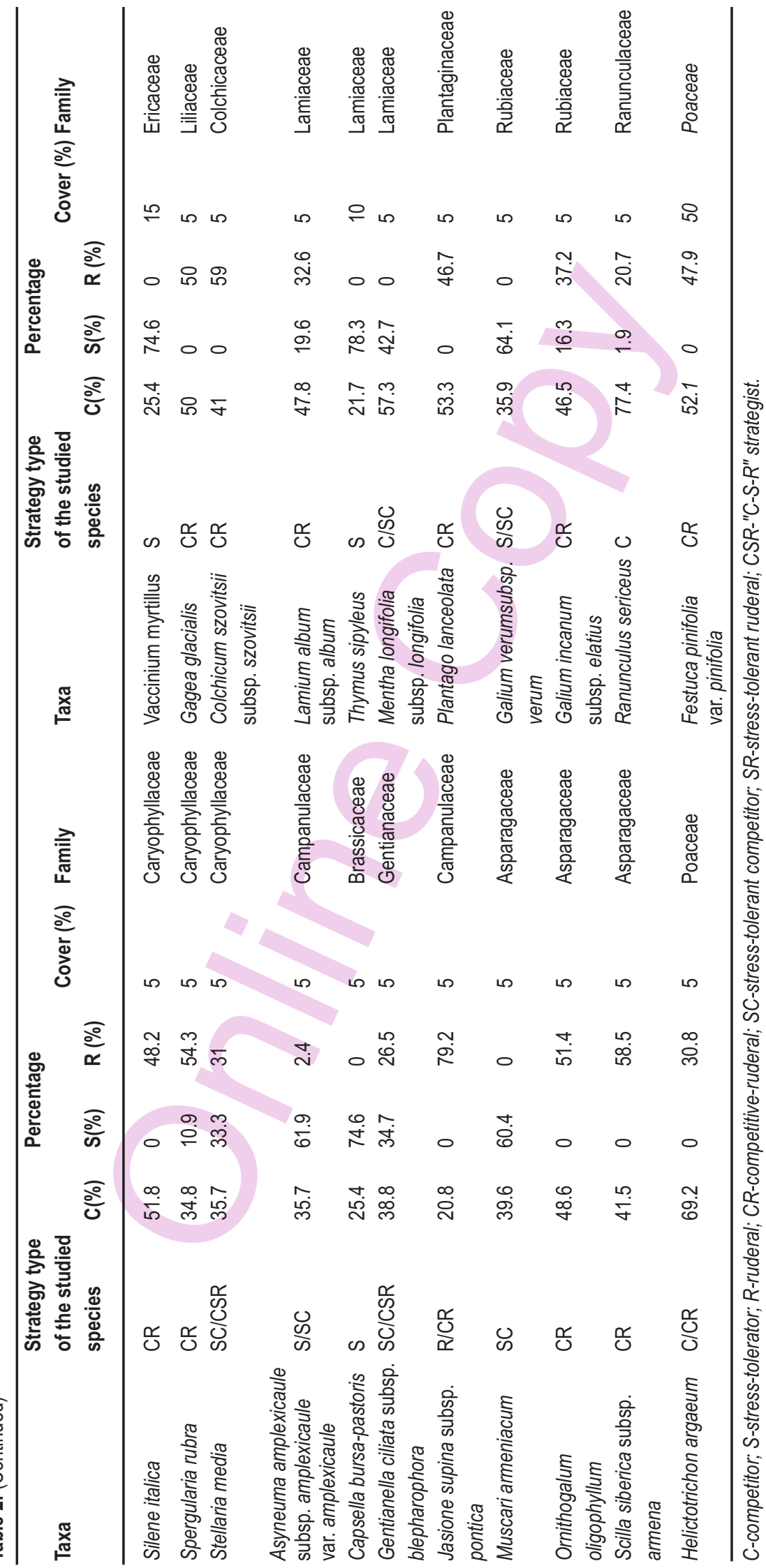


have a large proportion stress-tolerator strategy (S). Notably, these plant species and species that exhibited pure stresstolerator strategy $(\mathrm{S})$ realistically reflect their ecologies. As it is known, is that low temperature the dominant environmental stress in alpine belts and the growth of vascular plants is constrained due to short summer period. Additionally, plants in alpine regions are subject to other stress factors such as strong winds and intense solar radiation peculiar to high altitudes (Grime, 2002). Therefore, these plant species, particularly slower-growing perennials with tough leaves and low SLA values, were grouped together in the $S$ corner of the triangle (Fig. 1). There were large numbers of species that displayed SC strategy in the study area (Table 2). Species representing the stress-tolerant/competitor strategy were robust perennials of the sites with at least one maximum or minimum environmental factor. They differed from C-strategists in their capacity for lateral vegetative spread by means of rhizomes or expanding tussocks, lower maximum potential relative growth rates, longer life-span of leaves and shoot phenology that exhibits an entire reconciliation between that of the competitor and stress-tolerator (Grime, 2002; Zelnik and Čarni, 2008).

On the other hand, quite a higher number of plant species exhibited competitor-ruderal (CR), competitor/stress-tolerantcompetitor (C/SC), ruderal/competitor-ruderal (R/CR) and competitor/competitor-ruderal (C/CR) strategies having strong competition and ruderalism extents. Especially, competitorruderals were amongst the most frequent species (e.g., F. pinifolia var. pinifolia, Phleum alpinum) and subordinate geophytes such as Ornithogalum oligophyllum, Scilla siberica subsp. armena, Gagea glacialis and Colchicum szovitsii subsp. szovitsii. These subordinate geophytes have a complementary effect on the properties of ecosystems with dominant species and temporally exploit relatively unfavorable microhabitats making a minor contribution to the biomass of grasslands (Grime, 1998; Grime, 2006). This functional type occurred under two selective pressures, competition and disturbance. Grime (2002) defined competitor-ruderals as occurring in habitats in which dominance of the vegetation by competitors is prevented by a moderate intensity of disturbance. Paušič and Čarni (2012) pointed out that with agricultural land use change (abandonment), the ecological strategies of both plant species and the whole community change. Since traditional land management (e.g. grazing by cattle and sheep) prevails at moderate intensity in the study area, plant strategies shifted from S, SC, S/SC and SC/CSR towards $\mathrm{CR}, \mathrm{C} / \mathrm{CR}, \mathrm{R} / \mathrm{CR}$ and $\mathrm{C} / \mathrm{SR}$. The proportions of ruderalism reflect the degree of disturbance prevailing on different sites. Pierce et al. (2007) also stated that increased disturbance intensity encouraged both functional and species diversity, especially of ruderals and lesser co-dominance whereas dominant stresstolerating graminoids were suppressed. the present findings were consistent with these results. Species representing the S and SR strategies are also able to persist well concurrently on managed sites (Huhta and Rautio, 1998).
The presence of ruderals and CR strategists in the study area confirms that disturbance strongly influences niche segregation; faster-growing ruderals and competitive-ruderals necessarily require a local abundance of nutrients and are welladapted to propagate genes before ephemeral nutrient patches become exhausted due to their rapid inherent development and competition of the life-cycle (Pierce et al., 2007). Similar results were obtained by Hüseyinova et al. (2013). Guleryuz et al. (2010) also pointed out that in the alpine tundra, plant species have an important control on the soil $\mathrm{N}$ turnover, affecting the structure of the plant community and ecosystem function.

The results of the present study were compared with the reports of Grime et al. (2007) in the inland areas of Britain. Functional strategy types of only a few plant species (Agrostis stolonifera, Tussilago farfara, Lamium album subsp. album) were found similar to those obtained from the same species distributed in Europe, while lot of differences in strategy types of species were also found. For example, the deciduous shrub Vaccinium myrtillus L., which is a characteristic species in the alpine belt, displayed pure S-strategy in the study area, whereas Grime et al. (1998) classified this species as an SC-strategist. Also, roadside species Capsella bursa-pastoris (L.) Medik exhibited S-strategy in the present study, while Grime et al. (1998) found that C. bursapastoris displayed an $\mathrm{R}$ type strategy. These differences may be explained by habitat characteristics of the study area including altitude, soil structure, location, climate, light conditions, nutrient availability and intensity of disturbance factors. In fact, alpine belt plants are exposed to severe stress factors such as low temperature, strong wind, dryness, UV radiation, and short growing periods due to high altitudes. Thus, under these conditions the functional strategy of a species may change within CSR space. Similar results were reported by Hunt et al. (2004), Çakır et al. (2010), Kılınç et al. (2010), and Hüseyinova et al. (2013). Therefore, it is difficult to state that one species exhibits same strategy in all the habitats.

This study tried to classify competitive, stress-tolerant and ruderal strategies of some alpine belt plant species which lead to a change in the ecological strategies of plant species. This study suggested that, using easily-measured plant traits and standard vegetation methods might be useful on ecology and conservation efforts of alpine plant species in Turkey.

\section{Acknowledgments}

This study was funded by the Research Council of the Giresun University (Project Number A-250414-79). Special thanks to Ahmet Üstün and Yağmur Küçük for their support, administration and services.

\section{References}

Bond, W.J., F.I. Woodward and G.F. Midgley: The global distribution of ecosystem in a world without fire. New Phytol., 165, 525-538 (2005). 
Cerabolini, B., G. Brusa, R.M. Ceriani, R. De Andreis, A. Luzzaro and S. Pierce: Can CSR classification be generally applied outside Britain? Plant Ecol., 210, 253-261 (2010).

Craine, J.M.: Reconciling plant strategy theories of the Grime and Tilman. J. Ecol., 93, 1041-1052 (2005).

Cakır, Y.B., T. Ozbucak, H.G. Kutbay, D.D. Kılıç, A. Bilgin and R. Huseyinova : Nitrogen and phosphorus resorption in a salt marsh in northern Turkey. Turk. J. Bot., 34, 311-322 (2010).

Davis, P.H. (Ed.) : Flora of Turkey and the East Aegean Islands. Vol. 1-9, Edinburgh, Edinburgh University Press (1965-1985).

Davis, P.H., R.R. Mill and K. Tan (Eds.): Flora of Turkey and the East Aegean Islands. Vol. 10, (Suppl. I), Edinburgh, Edinburgh University Press (1988)

Diaz, S., S. Lavorel, S. Mclntyre, V. Falczuk, F. Casanoves, D.G. Milchunas, C. Scarpe, G. Rusch, M. Sternberg, I. Noy-Meir, J. Landsberg, W. Zhang, H. Clark and B.D. Campbell: Plant trait responses to grazing - a global synthesis. Global Change Biol., 13,313-341 (2007).

Grime, J.P.: Benefits of plant diversity to ecosystems: immediate, filter and founder effects. J. Ecol., 86, 902-910 (1998).

Grime, J.P.: Plant strategies, vegetation processes and ecosystem properties. $2^{\text {nd }}$ Edn., John Wiley and Sons, Chichester (2002).

Grime, J.P.: Trait convergence and trait divergence in herbaceous plant communities: Mechanisms and consequences. J. Veg. Sci., 17, 255-260 (2006)

Grime, J.P., J.G. Hodgson and R. Hunt: Comparative Plant Ecology : A functional approach to common British species. $2^{\text {nd }}$ Edn., Castlepoint Press, Colvend (2007).

Guleryuz, G., S. Gucel and M. Ozturk: Nitrogen mineralization in a high altitude ecosystem in the Mediterranean phytogeographical region of Turkey. J.Environ.Biol., 31, 503-514 (2010).

Guner, A., N. Ozhatay, T. Ekim and K.H.C. Başer (Eds.) : Flora of Turkey and the East Aegean Islands. Vol. 11, Edinburgh, Edinburgh University Press (2000).

Hodgson, J.G., P.J. Wilson, R. Hunt, J.P. Grime and K. Thompson: Allocating CSR plant functional types: A soft approach to a hard problem. Oikos, 85, 282-294 (1999).

Huhta, A.P. and P. Rautio: Evaluating the impacts of mowing: A case study comparing managed and abandoned meadow patches. Ann. Bot. Fenn., 35, 85-99 (1998).

Hunt, R., J.G. Hodgson, K. Thompson, P. Bungener, N.P. Dunnett and A.P. Askew: A new practical tool for deriving a functional signature for herbaceous vegetation. Appl. Veg. Sci., 7, 163-170 (2004).
Huseyinova, R., M. Kılınç, H.G. Kutbay, D.D. Kılıç and A. Bilgin: The comparison of Grime's strategies of plant taxa in Hacl Osman Forest and Bafra Fish Lakes in the Central Black Sea region of Turkey. Turk. J. Bot., 37, 725-734 (2013).

Keith, D.A., L. Holman, S. Rodoreda, J. Lemman and M. Bedword: Plant functional types can predict decade-scale changes in fire-prone vegetation. J. Ecol., 95, 1324-1337 (2007).

Kılınç, M., N. Karavin and H.G. Kutbay: Classification of some plant species according to Grime's strategies in a Quercus cerris L. var. cerris woodland in Samsun, Northern Turkey. Turk. J. Bot., 34, 521-529 (2010).

Magdi, M.A.: Plant functional types in Lake Nubia in relation to physicogeographic factors. Limnologica, 33, 305-315 (2003).

Navas, M.L., C. Roumet, A. Bellmann, G. Laurent and E. Garnier: Suites of plant traits in species from different stages of a Mediterranean secondary succession. Plant Biol., 12, 183-196 (2010).

Paušič, A. and A. Čarni: Functional response traits and plant community strategy indicate the stage of secondary succession. Hacquetia, 11, 209-225 (2012)

Pierce, S., A. Luzzaro, M. Caccianiga, R.M. Ceriani and B. Cerabolini: Disturbance is the principal a-scale filter determining niche differentation, coexistence and biodiversity in alpine community. $J$. Ecol., 95, 698-706 (2007).

Pierce, S., G. Brusa, I. Vagge and B. Cerabolini: Allocating CSR plant functional types: the use of leaf economics and size traits to classify woody and herbaceous vascular plants. Funct. Ecol., 27, 1002-1010 (2013).

Shryock, D.F., L.A. Defalco and T.C. Esque: Life-history traits predict perennial species response to fire in a desert ecosystem. Ecol. Evol., 4, 3046-3059 (2014).

Tilman, D.: Constraints and tradeoffs: toward a predictive theory of competition and succession. Oikos, 58, 3-15 (1994).

Vandvik, V. and H.J.B. Birks: Pattern and process in Norwegian upland grasslands: a functional analysis. J. Veg. Sci., 13, 123-134 (2002).

Zelnik, I. and A. Čarni: Distribution of plant communities, ecological strategy types and diversity along a moisture gradient. Community Ecol., 9, 1-9 (2008).

Zhu, Z.H., X.A. Wang, Y.N. Li, G. Wang and H. Guo: Predicting plant traits and functional types response to grazing in an alpine shrub meadow on the Qinghai-Tibet Plateau. Sci. China Earth Sci., 55, 837-851 (2012). 